\title{
Polychaete/amphipod ratios: An approach to validating simple benthic indicators
}

\author{
J.C. Dauvin ${ }^{\mathrm{a}, \mathrm{b}, \mathrm{c}, *},{ }$, H. Andrade ${ }^{\mathrm{d}}$, J.A. de-la-Ossa-Carretero ${ }^{\mathrm{e}}$, Y. Del-Pilar-Ruso ${ }^{\mathrm{e}}$, R. Riera ${ }^{\mathrm{f}}$ \\ a Normandie University, France \\ b UNICAEN, Laboratoire Morphodynamique Continentale et Côtière, UMR 6143 M2C, 24 rue des Tilleuls, F-14000 Caen, France \\ c CNRS, UMR 6143 M2C, 24 rue des Tilleuls, F-14000 Caen, France \\ d Akvaplan-niva, Fram Centre for Climate and the Environment, 9296 Tromsø, Norway \\ e Department of Marine Sciences and Applied Biology, University of Alicante, Ap 99 E-03080 Alicante, Spain \\ ${ }^{\mathrm{f}}$ Atlantic Environmental Marine Centre (CIMA SL), San Cristobal de La Laguna, Spain
}

\section{A R T I C L E I N F O}

\section{Article history:}

Received 25 August 2015

Received in revised form

25 November 2015

Accepted 28 November 2015

Available online 22 December 2015

\section{Keywords:}

Polychaete/amphipod ratio

Taxonomic Sufficiency

Indicators

Oil spill

Sewage pollution

Brine

Aquaculture farms

\begin{abstract}
A B S T R A C T
Among the macro-invertebrates used for the assessment of soft-bottom communities, most polychaetes are classified as tolerant/opportunistic to pollution while amphipods are considered as sensitive. These taxa have been used in several ecological indices, such as the simple abundance ratio between Polychaeta and Amphipoda or the Benthic Opportunist Annelids Amphipods (BO2A) index, to assess the Ecological Quality Status -EcoQs- of soft-bottom communities. In terms of Taxonomic Sufficiency (TS), the polychaete/amphipod ratio (i.e. at the level of the class/order) has been proved to be effective in identifying major changes in benthic communities following disturbances. However, an underlying issue is to assess the acceptable TS limit value needed to state accurately the quality of the benthic environment. We tested three indices using 18 series of observations carried out in five north-eastern Atlantic and Mediterranean zones impacted by oil spills, oil and gas production, brine and urban sewage, harbours and aquaculture farms within impacted and control areas. Similar results to BO2A were obtained when limiting the TS at the level of Polychaete opportunistic families, which required a lower degree of taxonomic expertise, and classifying all amphipods as sensitive taxa. In such a way that the EcoQs given by the BPOFA (Benthic Polychaete Opportunistic Families Amphipods) was very similar to those given by the BO2A (Benthic Opportunistic Annelids Amphipods).
\end{abstract}

(c) 2015 Elsevier Ltd. All rights reserved.

\section{Introduction}

The development of benthic biological indicators that were able to identify environmental status and potential anthropogenic impacts (Diaz et al., 2004) has recently attracted much research effort in Europe. The European Water Framework Directive (WFD; 2000/60/EC) spurred the development of innovative ecological indicators (Devlin et al., 2007), mostly for the quality assessment of soft-bottom macrobenthic communities (see Borja et al., 2009; Pinto et al., 2009; Martinez-Haro et al., 2015). In 2008, the Marine

\footnotetext{
* Corresponding author at: Laboratoire Morphodynamique Continentale et Côtière, UMR 6143 M2C, 24 rue des Tilleuls, F-14000 Caen, France. Tel.: +332315657 22; fax: +33231565757.

E-mail addresses: jean-claude.dauvin@unicaen.fr

(J.C. Dauvin), hector.andrade@akvaplan.niva.no (H. Andrade),

ja.ossa@ua.es (J.A. de-la-Ossa-Carretero), yoana.delpilar@ua.es (Y. Del-Pilar-Ruso), rodrigo@cimacanarias.com (R. Riera).
}

Strategy Framework Directive (MSFD; 2008/56/EC) reinforced the need to develop ecological indicators to assess the Quality Status of European marine waters (see Van Hoey et al., 2010; Rombouts et al., 2013). Most ecological indicators are based on the long established principle of tolerant/sensitive species (i.e. species favoured by pollution/species affected by pollution). Reish (1959) first suggested this principle in the 1950s, while Pearson and Rosenberg (1978) established this concept in their review of the response of benthic species and communities to organic matter enrichment. Later, according to the Pearson and Rosenberg (1978) paradigm, Glémarec and Hily (1981) and Grall and Glémarec (1997) proposed classifying macrobenthic species in five ecological groups in terms of defining sensitive/tolerant/proliferating species in response to organic matter enrichment. Borja et al. (2000) adopted the same representation of species proportions, arranged in five ecological groups, for calculating the AZTI Marine Biotic Index (AMBI), which was developed for the European Water Framework Directive (WFD). In the same way, Simboura and Zenetos (2002) also proposed a new index (BENTIX) developed for the Mediterranean 
Sea. This index was based on the relative percentages of three ecological groups of species grouped according to their sensitivity or tolerance to disturbance factors and weighted proportionately to obtain a formula rendering a five step numerical scale of ecological quality classification.

Amphipods are an abundant component of the estuarine and marine soft-bottoms and are known to be sensitive to polluted sediments; they disappeared from benthic communities impacted by pollution and could reappear when environmental condition recover (Ré et al., 2009; de-la-Ossa-Carretero et al., 2012a). Similar to the known responses of benthic species to organic matter enrichment, other sources of pollution, such as oil spills, have allowed researchers to observe the sensitivity or tolerance of benthic species to hydrocarbons in the water column and/or sediments (Gomez-Gesteira and Dauvin, 2000, Gomez-Gesteira et al., 2003). Crustaceans, especially amphipods, seemed to be affected by low levels of hydrocarbons, while other species, such as polychaetes, were mostly tolerant to high levels of hydrocarbons (GomezGesteira and Dauvin, 2000; Gomez-Gesteira et al., 2003). Since hydrocarbon pollution was similar to an organic matter increase (i.e. available carbon), both produced the same results in benthic communities: the selection and proliferation of a small number of opportunistic species, such as oligochaetes and polychaetes, and a decrease of sensitive species such as amphipods. Amphipod sensitivity have been highlighted by several authors since the beginning of the 1980s (Bellan-Santini, 1980) and continued to be discussed (Ré et al., 2009; de-la-Ossa-Carretero et al., 2012a). These studies have led to the development of benthic quality indices based on the ratio of sensitive amphipods to other fauna mainly comprised of opportunistic polychaetes or annelids (Gomez-Gesteira and Dauvin, 2000; Dauvin and Ruellet, 2007, 2009). Moreover, the amphipod abundances and opportunistic capitellids, or the abundance of sensitive species compared with tolerant species, have been included in several multimetric approaches such as those used for the Benthic Index of Environmental Condition of the Gulf of Mexico estuaries (Ponti et al., 2009) or the Macrobenthic Index of Sheltered Systems developed by Lavesque et al. (2009) for the Zostera noltei beds in the Arcachon Basin (French Atlantic coast).

The indices BOPA (Benthic Opportunistic Polychaetes Amphipods; Dauvin and Ruellet, 2007) and BO2A (Benthic Opportunistic Annelids Amphipods; Dauvin and Ruellet, 2009) were obtained as the $\log _{10}$ of the ratio between opportunistic polychaetes (or annelids) and amphipod frequencies (i.e. the total number of opportunistic polychaetes (or annelids) and total number of amphipods divided by the overall abundance accounted in a sample). Andrade and Renaud (2011) employed a general polychaete/amphipod ratio to assess the impact of offshore oil and gas production on benthic fauna along the Norwegian continental shelf. They found that the ratio between tolerant (polychaetes) and sensitive (amphipods) species decreased across a distance gradient from the production facility to the less impacted stations.

To consider a polychaete/amphipod ratio (i.e. at the class or order level) as an indicator of benthos quality in terms of Taxonomic Sufficiency (TS) (Ellis, 1985), it is required: (1) an identification level higher than the species (i.e. genus, family, order, class), and (2) the use of amphipods and polychaetes as surrogates for benthic assessments (Dauvin et al., 2003; Gomez-Gesteira et al., 2003; Terlizzi et al., 2003; Bevilacqua et al., 2009; Tataranni et al., 2009; Musco et al., 2009, 2011; Soares-Gomes et al., 2012; de-la-OssaCarretero et al., 2012b; Aguado-Giménez et al., 2015). Although the TS was often presented as being cost-effective (Tataranni and Lardicci, 2010; Andrade and Renaud, 2011; Dimitriou et al., 2012), many authors have disregarded its use arguing that until now, no studies have compared directly the TS level required to effectively assess benthic environmental quality. The goal of the present study was to compare the effectiveness of three indices employing TS, the Opportunistic Annelids Amphipods index (BO2A) (Dauvin and Ruellet, 2007, 2009), the Benthic Polychaete Opportunistic Families Amphipods index (BPOFA) and the Benthic Polychaetes Amphipods index (BPA), to detect changes of environment quality in softbottom communities. For this purpose, we analysed data collected at different locations across a large latitudinal gradient under different anthropogenic pressures. The locations extended from coastal zones with high input of continental organic matter to offshore oligotrophic zones in the north-eastern Atlantic, including the Norwegian continental shelf, Brittany (NW France) and Galicia (NW Spain), as well as the Canarian archipelago and the western basin of the Mediterranean Sea (Castellón coast, NE Spain). Anthropogenic pressures included oil spills (Brittany and Galicia), offshore oil and gas production (Norway), urban sewage (Castellón coast), fish cages and harbour construction, as well as brine and sewage discharge (Canarian Archipelago). The underlying issue was to identify the limit of acceptable TS to assess accurately the quality of the benthic environment using macrofauna, i.e. polychaetes (or annelids) and amphipods.

\section{Materials and methods}

Data previously collected during different sampling campaigns were used to test the three indices. A total of 18 selected sites located along a latitudinal gradient in the north-eastern Atlantic Ocean and the western basin of the Mediterranean Sea was selected.

\subsection{Study sites}

The data came from:

- Three oil and gas production fields (Ekofisk 2/4B\&K (hereby Ekofisk), Statfjord A and Heidrun) located in the continental shelf off Norway. These fields were sampled as part of an environmental monitoring programme from 1990 to 2009. The benthic data includes species abundances collected every 3 years along a distance gradient, from the production facility to reference stations located at least $10,000 \mathrm{~m}$ away. Abundance data were grouped in five distance categories $(0-250 \mathrm{~m} ; 250-500 \mathrm{~m} ; 500-2000 \mathrm{~m}$; 2000-5000 $\mathrm{m}$, and $>10,000 \mathrm{~m}$ respectively) [for further information see Andrade and Renaud (2011) and references therein].

- Two sites (Rivière de Morlaix, RM and Pierre Noire, PN) from a long term survey (1977-1996) in the Bay of Morlaix (Brittany coast of western English Channel, NW France) polluted by hydrocarbons coming from the Amoco Cadiz wreck in April 1978 [for further information see Dauvin (1998) and Dauvin (2000)].

- Five sites from two different sectors in the Ares-Betanzos Ría, Galicia, NW Spain sampled after the spill of the Greek tanker Aegean Sea (December 1992-November 1996) [for further information Gomez-Gesteira and Dauvin (2000, 2005)].

- Four sites at two distances from the discharge outfall (0 and $1000 \mathrm{~m}$ ) affected by sewage discharge along the Castellón coast (Mediterranean Sea, NE Spain) and sampled for five consecutive summers (2004-2008) [for further information see de la Ossa Carretero et al., 2008; Del-Pilar-Ruso et al., 2009; de-la-OssaCarretero et al. (2008, 2009 and 2010)].

- Four sites from the Canarian Archipelago, being subjected to different anthropogenic disturbances: fish cages (Barranco Hondo, April 2007-December 2008), turbidity and sediment load (Calero harbour, November 2004-June 2006), brine (Las Burras, May 2008-January 2009), brine and sewage (Tarajalillo, May 2008-January 2009) [for further information see Riera and de-laOssa Carretero (2013)]. 


\subsection{Data analysis}

The three indices were defined as follows:

1) BO2A (Benthic Opportunistic Annelids Amphipods) (Dauvin and Ruellet, 2009):

$$
B O 2 A=\log _{10}\left[\frac{f_{\text {oa }}}{f_{\mathrm{sa}}+1}+1\right]
$$

where $f_{\text {oa }}$ is the frequency of opportunistic annelids (Clitellata and Polychaeta) (i.e. number of opportunistic polychaetes corresponding to the Ecological Groups IV and V of Grall and Glémarec (1997) and used for calculating AMBI (Borja et al., 2000), plus the Oligochaeta and Hirudinea, divided by the overall abundance in a sample), $f_{\text {sa }}$ was the sensitive amphipod frequency (i.e. number of amphipods, excluding the opportunistic Jassa amphipods, divided by the overall abundance in a sample), and $f_{\mathrm{oa}}+f_{\mathrm{sa}} \leq 1$.

2) A new index, designated as BPOFA (Benthic Polychaete Opportunistic Families Amphipods):

$B P O F A=\log _{10}\left[\frac{f_{\text {pof }}}{f_{\mathrm{a}}+1}+1\right]$

where $f_{\text {pof }}$ was the frequency of opportunistic polychaete families (i.e. Capitellidae, Cirratulidae, Dorvilleidae, Pectinariidae and Spionidae) and $f_{\mathrm{a}}$ was the frequency of all amphipods including Jassa. To obtain results that were comparable with BO2A, the BPOFA index was calculated with the same equation of BO2A.

3) The BPA a Benthic Polychaetes Amphipods ratio:

$B P A=\log _{10}\left[\frac{f_{\mathrm{p}}}{f_{\mathrm{a}}+1}+1\right]$

where $f_{\mathrm{p}}$ was the polychaete frequency and $f_{\mathrm{a}}$ is the amphipod frequency. This index corresponded to the ratio between the polychaete abundance in a sample and the total amphipod abundance; BPA index was calculated with the same equation of $\mathrm{BO} 2 \mathrm{~A}$.

As the computation of BO2A was not recommended for samples containing $\leq 20$ individuals (Dauvin and Ruellet, 2009), the same threshold was required for BPOFA and BPA. According to Dauvin and Ruellet (2009) BOPA values were in the range from 0 to $\log _{10}$ $2=0.301$; this range was also considered for BPOFA and BPA.

The stations for each locality were classified in two levels: impacted and control stations. For the continental shelf of Norway, impacted stations corresponded to stations near the production facility $(<2000 \mathrm{~m})$, and control stations to the stations located at least at $5000 \mathrm{~m}$ from the production facility (Andrade and Renaud, 2011). For the Bay of Morlaix, the Rivière de Morlaix station in the inner part of the Bay corresponded to the impacted station, while the control station was Pierre Noire. In Galicia, the impacted
Table 1

Thresholds for establishing EcoQ status by each index. Values $<0.025 \rightarrow$ High Status; Values $0.025-0.130 \rightarrow$ Good Status; Values $0.130-0.199 \rightarrow$ Moderated Status; Values $0.199-0.255 \rightarrow$ Poor Status, and Values $>0.255 \rightarrow$ Bad Status.

\begin{tabular}{llll}
\hline & BO2A & BPOFA & BPA \\
\hline High-Good & 0.025 & 0.031 & 0.135 \\
Good-Moderate & 0.130 & 0.126 & 0.211 \\
Moderate-Bad & 0.199 & 0.187 & 0.260 \\
Poor-Bad & 0.255 & 0.237 & 0.300 \\
\hline
\end{tabular}

stations were located in the inner part of the ría, while the control stations were in the central zone of the ría. In Castellón (western Mediterranean), the impacted stations corresponded to the stations near the discharges, while control stations were at $1000 \mathrm{~m}$ from the discharges. Finally for the Canarian Archipelago, the impacted stations where those affected by human activities, while the control stations corresponded to stations unaffected by these diverse human activities.

An analysis of variance (ANOVA), with a fixed factor with this two levels, impact and control, was used in order to test differences in the three indices. Prior to ANOVA, the homogeneity of variance was tested using Barlett's test. Data were transformed when variances were significantly different. If variance remained heterogeneous, untransformed data were analysed since ANOVA is robust to heterogeneity of variances, particularly for large balanced experiments (Underwood, 1997). We set a more conservative significance level of 0.01 to reduce the probability of a Type I error.

Pearson's correlation coefficient $r$ was used to test the relationships between the three indices (BO2A, BPOFA and BPA), i.e. the couples BO2A-BPOFA, BO2A-BPA and BPOFA-BPA. The level of agreement between the indices will be determined by the strength of correlation $(r=-1,1)$. Higher values of $r$ will led to a higher agreement. Besides, thresholds have been provided for establishing Ecological Status of each site, which led us to evaluate the consequences of choosing any of these indices for assessing an impact.

Thresholds, presented by de-la-Ossa-Carretero and Dauvin (2010) for BO2A, were used for establishing Ecological Status of each sample from a pristine ecosystem state to highly degraded state: high, good, moderate, poor or bad (Table 1). Thresholds of BPOFA and BPA were obtained from these BO2A thresholds by a regression using the whole dataset (Table 2). Weighted Kappa analysis (Cohen, 1960; Landis and Kosch, 1977) was used to evaluate the agreement, employing the methodology proposed by Borja et al. (2007). The equivalence table from Monserud and Leemans (1992) was used to establish the level of agreement of the two indices. In addition, since the importance of misclassification is not the same between close categories (e.g. between high and good, or poor and bad) as between distant categories (e.g. between high and moderate, or high and bad), we chose to apply Fleiss-Cohen weights (Fleiss and Cohen, 1973).

Table 2

Results of ANOVA for BPA, BPOFA and BO2A values between impact and control stations for each study site. Df: degrees of freedom, $F^{p}: F$ ratio and $p$-value.

\begin{tabular}{|c|c|c|c|c|c|c|c|c|c|c|c|}
\hline & & \multicolumn{2}{|c|}{ Norway } & \multicolumn{2}{|c|}{ Bay of Morlaix } & \multicolumn{2}{|c|}{ Galicia } & \multicolumn{2}{|c|}{ Castellón } & \multicolumn{2}{|c|}{ Canary Archipelago } \\
\hline & & Df & $F^{\mathrm{p}}$ & Df & $F^{\mathrm{p}}$ & Df & $F^{p}$ & Df & $F^{\mathrm{p}}$ & Df & $F^{\mathrm{p}}$ \\
\hline \multirow[t]{2}{*}{ BPA } & IC & 1 & $31.77<0.001$ & 1 & $127.5^{<0.001}$ & 1 & $171.2<0.001$ & 1 & $29.16^{<0.001}$ & 1 & $64.48<0.001$ \\
\hline & Res & 267 & & 38 & & 54 & & 38 & & 175 & \\
\hline \multirow[t]{2}{*}{ BPOFA } & IC & 1 & $67.13<0.001$ & 1 & $76.12<0.001$ & 1 & $0.033^{0.875}$ & 1 & $15.69<0.001$ & 1 & $28.85^{<0.001}$ \\
\hline & Res & 267 & & 38 & & 54 & & 38 & & 175 & \\
\hline \multirow[t]{2}{*}{$\mathrm{BO} 2 \mathrm{~A}$} & IC & 1 & $75.48<0.001$ & 1 & $73.13<0.001$ & 1 & $0.8161^{0.358}$ & 1 & $15.59<0.001$ & 1 & $1.341^{0.248}$ \\
\hline & Res & 267 & & 38 & & 54 & & 38 & & 175 & \\
\hline
\end{tabular}




\section{Results}

\subsection{Values of the indices in control and impacted stations}

Impacted stations presented higher indices values than control stations for most of the sites, i.e. lower ecological status (Fig. 1). In a comparable way, the values of BPA were higher than those of

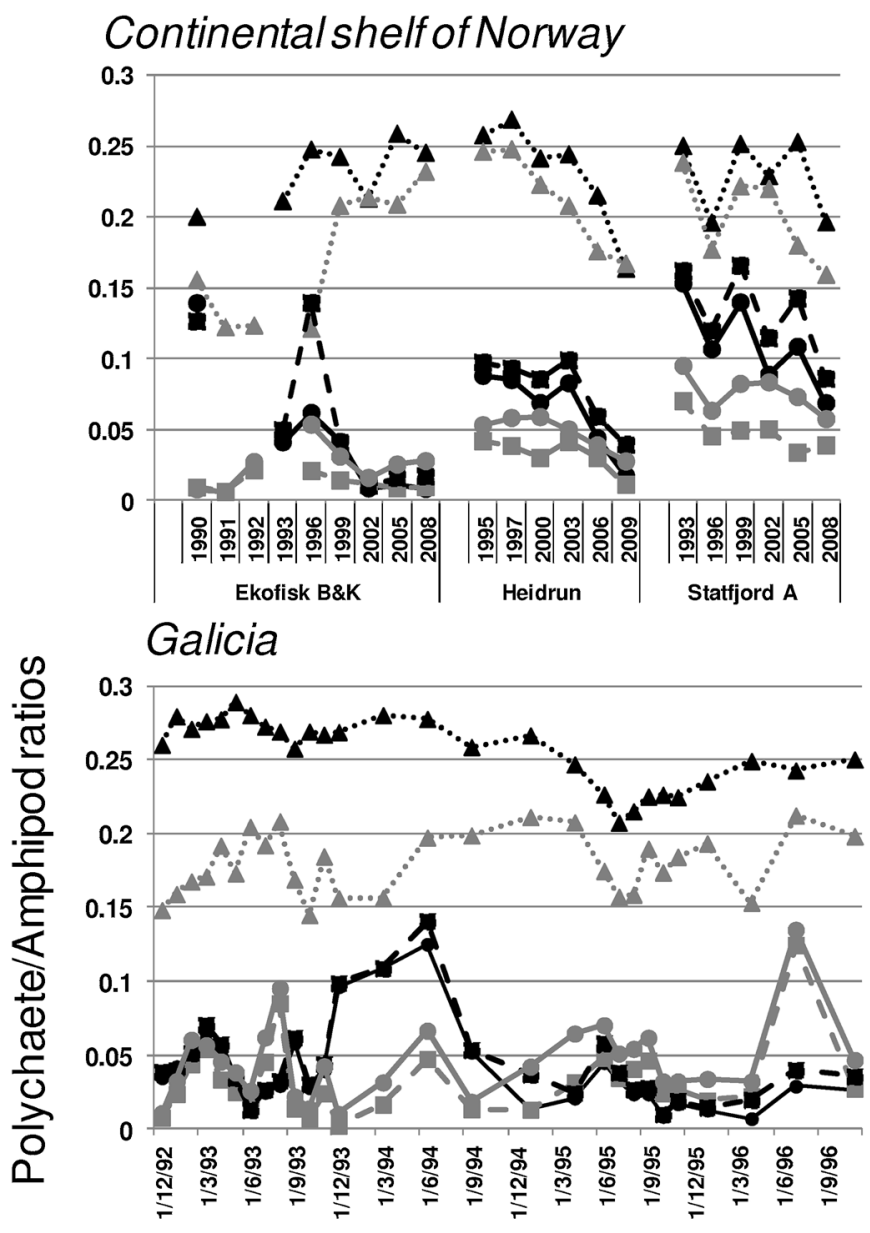

\section{Canarian Archipelago}

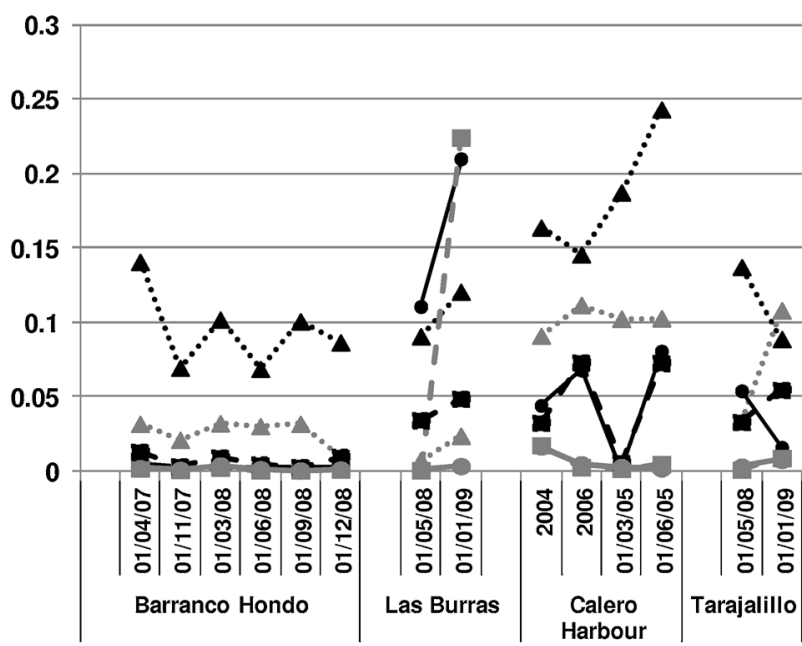

the two other indices BPOFA and BO2A which showed very similar values with the points often superposed (Fig. 2), in particular for the Bay of Morlaix, Galicia and Castellón coast sites.

For the continental shelf Norway, the three indices showed similar patterns in such a way that significant differences were detected between impact and control stations (Table 2). They were higher at impacted stations closer to the production facility than

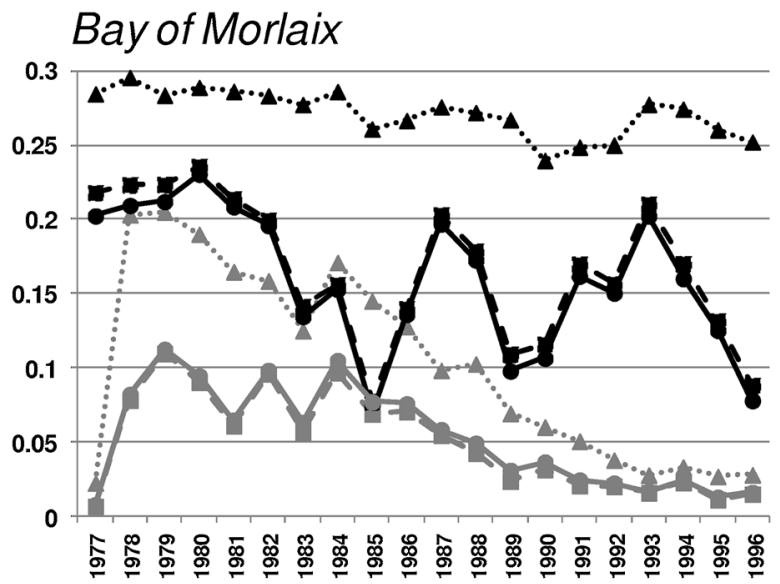

Castellón coast

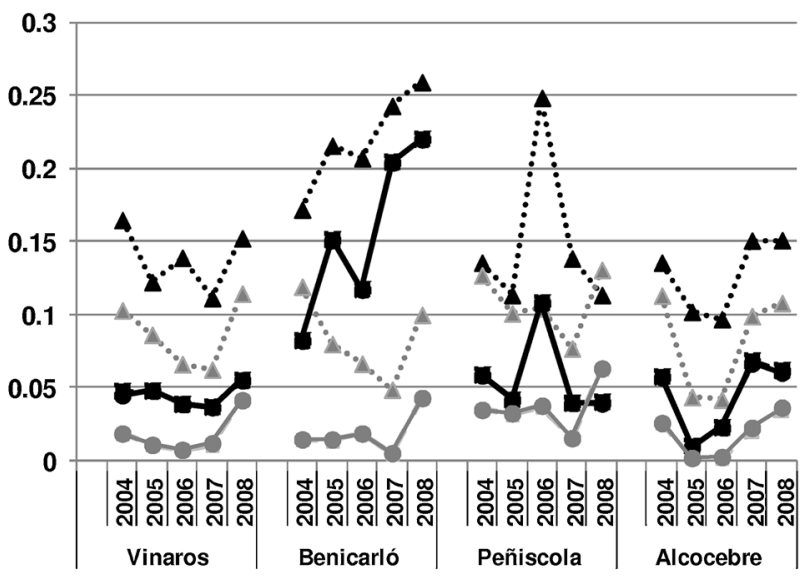

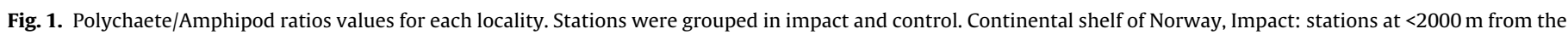

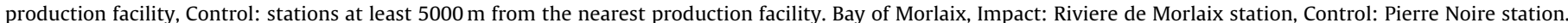

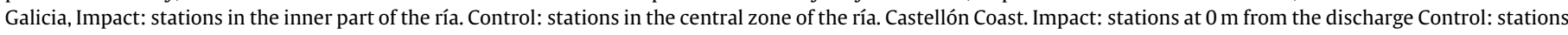
at $1000 \mathrm{~m}$ from the discharge. Canarian Archipelago: Impact: impacted stations, Control: control stations. 

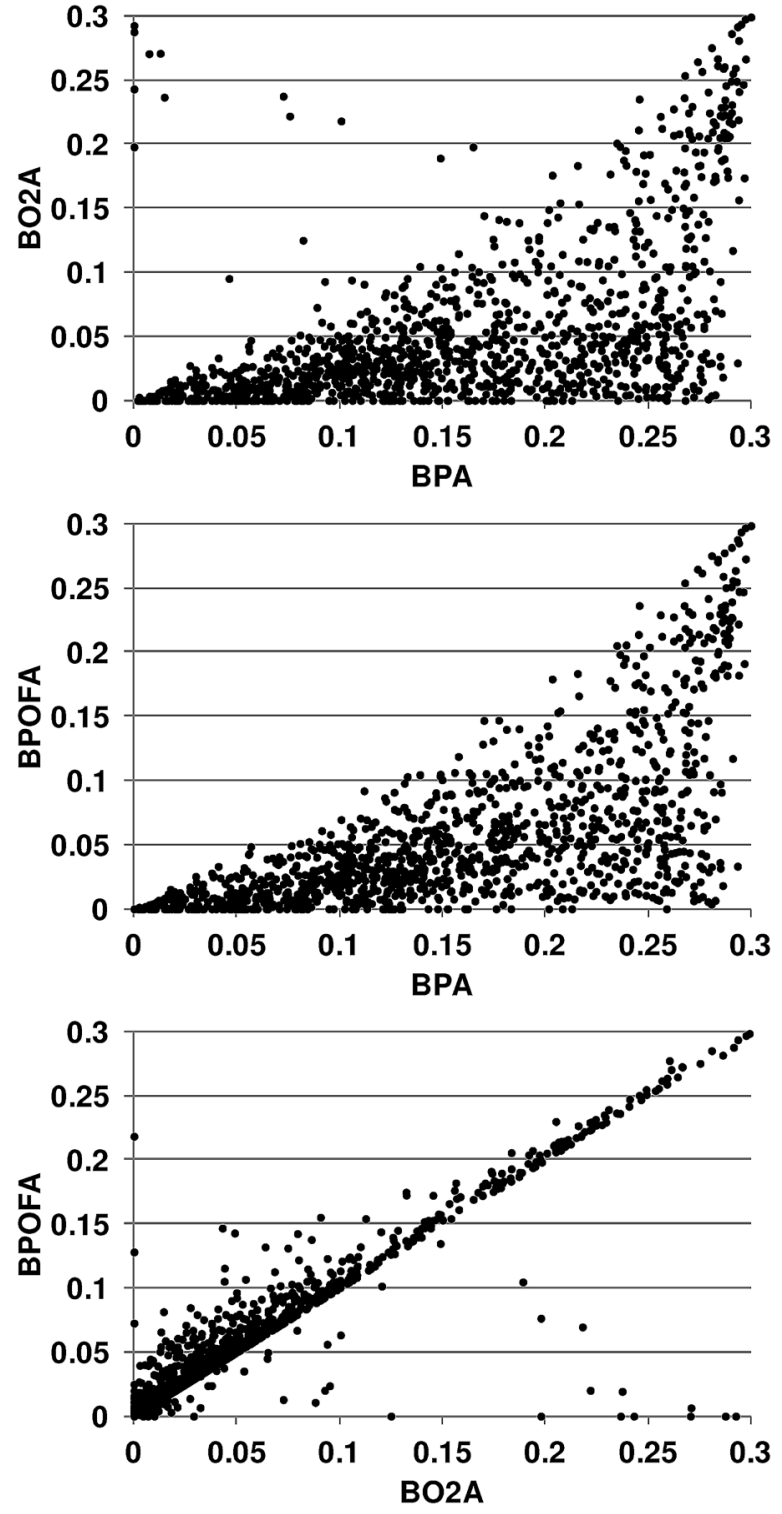

Fig. 2. Scatter plots between pair of values of each Polychaete/Amphipod ratios.

stations distant to them. For the Ekofisk field, BO2A and BPOFA indices showed clearer trends when compared with BPA values, which, in 2005, showed a maximum (Fig. 1). In 1996, the BPOFA and BPA indices showed a peak in the impacted stations. For the Heidrun field, the three indices showed generally the same pattern of decrease towards values of the control station. In 1997, the BPA index showed a peak. By 2009, the three indices at the impacted stations had reached similar values to those found at the control stations. For the Statfjord A field, BPA remained high obtaining a less clear temporal pattern whilst BO2A and BPOFA showed a clearer decreasing trend since 1999. The number of amphipods used to calculate the three different indices for Heidrun and Statfjord A remained constant since no tolerant species were recorded in these sites. For Ekofisk, few tolerant amphipods were recorded (genus Jassa, $\mathrm{n}=14$ out of 1033). Differences in these sites can be therefore be primarily ascribed to the numbers of polychaetes used in the index computations.

In the Bay of Morlaix, both BO2A and BPOFA indices showed similar temporal patterns, with higher values and variability at the impacted RM station than at the control PN station (Fig. 1). Significant differences were also detected between impact and control stations for the three indices in this site (Table 2). At the control site, there was a large increase of the indices in particular BPA at the beginning of the survey, and lately a general trend to decreasing values. The BPA index remained very high throughout the survey period in the RM impacted station.

In Galicia, both BO2A and BPOFA showed similar patterns with fluctuating peaks, which did not follow a distinct temporal trend. There was no indication of the impact of the 'Aegean Sea' oil spill and the temporal changes were synchronous, without any clear differences between impacted and control stations (Fig. 1, Table 2). The values of both indices remained relatively low $(<0.15)$. However, significant differences were detected in BPA index between impact and control stations, with higher values in impacted stations. This index showed a general decrease at the impacted stations from the peaks of June 1993 to June 1995 whilst values in control stations were more stable, ranging from 0.15 to 0.20 .

On the Castellón coast, the three indices showed a clear response to the discharge, with lower values in control stations than impacted sites closer to the sewage discharge, where amphipod abundance decreased and polychaete abundance increased (Fig. 1, Table 2). At Benicarló, there was a greater difference of values between impacted and control station, especially in 2007 and 2008. Marked differences for the BPA index were observed in other locations, such as Peñíscola (2006) or Alcocebre (2007).

In the Canarian Archipelago, the three indices showed very low values including a high number of zero results due to the absence of opportunistic species. Significant differences were detected in BPA and BPOFA between control and impact stations (Table 2). These differences were more noticeable in Calero Harbour, while an increase could be identified at the Las Burras desalination plant site (Fig. 1). At the Barranco Hondo fish cages, BPOFA and BO2A indices showed very low values. Higher values were observed mainly at the impacted stations, with maximum values attained in April 2007 and December 2008.

\subsection{Relationships between the three indices}

The Pearson coefficients between the three indices showed significant correlations at most of the sites (Table 3). Except for the Canarian archipelago dataset, where the majority of the Pearson coefficient values between pairs of indices were low and nonsignificant (three out of 15 possible). Nevertheless, the strength of these significant correlations varied between indices. The correlations between BPA and both other indices were weaker than

Table 3

Pearson coefficient values between couples of indices for each area and site. In bold, the non-significance level $(p>0.05)$.

\begin{tabular}{lllll}
\hline \multirow{2}{*}{ Norway } & & BO2A/BPOFA & BO2A/BPA & BPOFA/BPA \\
& Total & 0.960 & 0.490 & 0.483 \\
& Ekofisk 2/4B\&K & 0.932 & 0.322 & 0.346 \\
& Heidrun & 0.974 & 0.698 & 0.690 \\
Bay of Morlaix & Statfjord & 0.978 & 0.670 & 0.689 \\
& Total & 0.998 & 0.798 & 0.811 \\
& Pierre Noire & 0.998 & 0.795 & 0.812 \\
Galicia & Rivière de Morlaix & 0.996 & 0.513 & 0.51 \\
& Total & 0.952 & 0.337 & 0.281 \\
& Inner part & 0.982 & 0.355 & 0.336 \\
Castellón & Central part & 0.937 & 0.489 & 0.577 \\
& Total & 1.000 & 0.844 & 0.845 \\
Canary & 0 m & 1.000 & 0.857 & 0.859 \\
Archipelago & 1000 m & 0.997 & 0.679 & 0.677 \\
& Total & 0.390 & $\mathbf{0 . 2 1 6}$ & 0.365 \\
& Barranco Hondo & $\mathbf{0 . 0 7 3}$ & 0.640 & $\mathbf{0 . 1 1 8}$ \\
& Las Burras & $\mathbf{0 . 4 4 8}$ & $\mathbf{0 . 3 3 0}$ & 0.971 \\
& Calero Harbour & $\mathbf{0 . 4 6 7}$ & $\mathbf{0 . 3 9 8}$ & $\mathbf{0 . 4 8 1}$ \\
& Tarajalillo & $\mathbf{0 . 4 6 9}$ & $\mathbf{0 . 1 3 6}$ & $\mathbf{0 . 6 9 2}$ \\
\hline
\end{tabular}


those between BO2A and BPOFA (Table 3). Scatter plots allowed for a visual inspection of the relations between pairs of values of the three indices (Fig. 2). The relation between BO2A and BPOFA was linear, showing that there is a high agreement between both indices. The relation between BPA and the other indices was less clear with a high dispersion of values between BO2A and BPA and between BPOFA and BPA (Fig. 2).

\subsection{Ecological status}

The Fig. 3 gives the distribution in percentage of each EcoQ Status (EcoQS) of each site for impact and control stations.

BO2A and BPOFA classified control stations as high and good status, except in Canarian Archipelago where 7\% of control stations were classified as moderate, poor or bad by BPOFA. Both indices tended to assigned worse EcoQs to a higher percentage of impact stations with respect to control stations, being BPOFA stricter in most of the areas. Only in the case of Galicia, differences between impact and control stations were not detected using BO2A and BPOFA. Regarding to BPA, it assigned worse EcoQs (moderate, poor or bad) to a higher percentage of impact stations in comparison with control stations. However, this ratio also classified control stations as moderate or poor in Norway and Galicia. Kappa analysis showed a high agreement between BO2A and BPOFA in most of the areas with the exception of Galicia and the Canarian Archipelago where level of agreement was low (Table 4). The other comparisons
Table 4

Kappa values with agreement levels in parentheses for the Ecological Status classification between each indices (level of agreement: AP-'Almost perfect'; VG-'Very good';G-'Good'; M-'Moderate', L-'Low', N-'Null').

\begin{tabular}{llll}
\hline & BO2A/BPOFA & BO2A/BPA & BPOFA/BPA \\
\hline Total & $0.7715(\mathrm{VG})$ & $0.3203(\mathrm{~L})$ & $0.4479(\mathrm{M})$ \\
Norway & $0.9018(\mathrm{AP})$ & $0.2825(\mathrm{~L})$ & $0.3186(\mathrm{~L})$ \\
Bay of Morlaix & $0.9435(\mathrm{AP})$ & $0.7007(\mathrm{VG})$ & $0.7774(\mathrm{VG})$ \\
Galicia & $0.3408(\mathrm{~L})$ & $0.0315(\mathrm{~N})$ & $0.0330(\mathrm{~N})$ \\
Castellón & $0.9940(\mathrm{AP})$ & $0.7610(\mathrm{VG})$ & $0.7472(\mathrm{VG})$ \\
Canary Archipelago & $0.251(\mathrm{~L})$ & $0.122(\mathrm{~L})$ & $0.5843(\mathrm{G})$ \\
\hline
\end{tabular}

with BPA showed worse level of agreement except in the case of Canarian Archipelago where the highest agreement was obtained between BPOFA and BPA.

In summary, the indices indicate: (i) a worse EcoQS in impact stations than in control stations when we take into account the three indices, and (ii) the BPA gives a more severe classification than the two other indices.

\section{Discussion}

A very strong correlation between the BO2A and BPOFA indices were detected in this study, except for the Canarian archipelago, where very low indices were detected (Table 3). Consequently, these indices might be unsuitable for assessing environmental

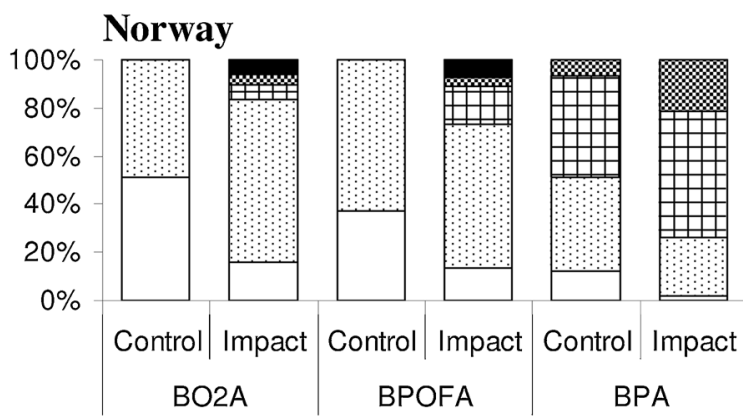

\section{Bay of Morlaix}

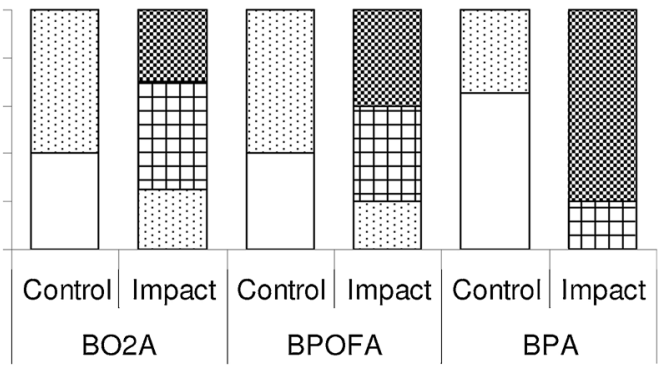

Castellón
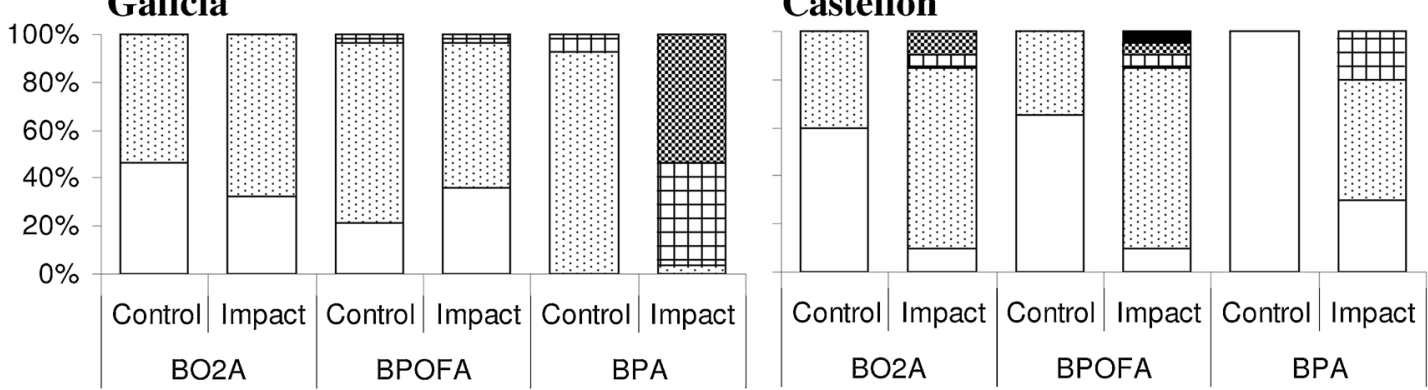

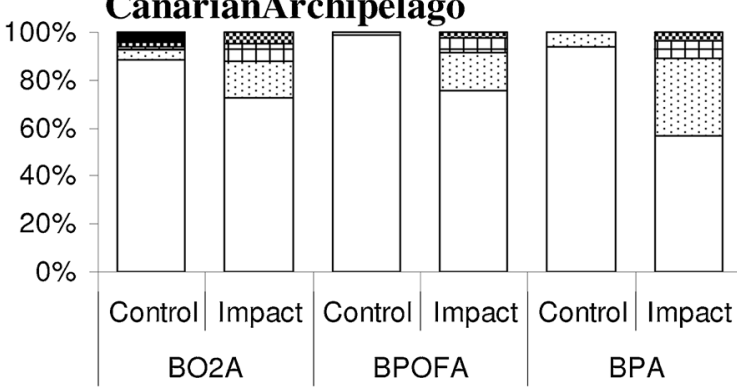

$\square \mathrm{HIGH}$ GOOD

田 MODERATE $\otimes$ POOR

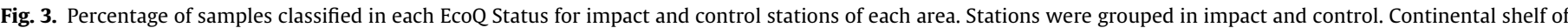

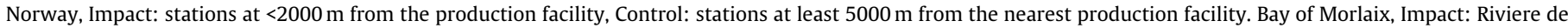

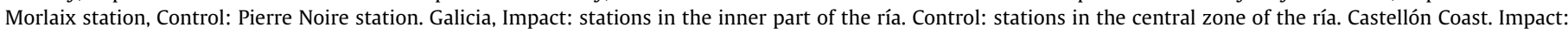
stations at $0 \mathrm{~m}$ from the discharge Control: stations at $1000 \mathrm{~m}$ from the discharge. Canarian Archipelago: Impact: impacted stations, Control: control stations. 
quality at this and other similar locations. In this location, indices were very low probably due to the oligotrophic nature of the Atlantic Ocean in the Canaries, which might dissipate perturbations brought about the anthropogenic disturbances analysed in this study (Riera and de-la-Ossa-Carretero, 2013).

Man-induced perturbations in the Canarian archipelago are spatially limited and characterized by a low intensity in the impacted area, being classified coastal water masses as in very good condition (Riera et al., 2009). Pollution from sewage and desalination plants is rapidly diluted in the water column because of the continuous coastal currents. Thus, macrofauna community is not heavily affected by this perturbation, and the composition of polychaetes and amphipods not differ consistently from impacted to control stations (Riera et al., 2012). This situation occurs in offshore fish cages, with a high dispersion of particulate material, e.g. faeces and uneaten pellets, together with the presence of fish aggregates that incorporate this food source as a main part of their diet (Riera et al., 2014). The three indices (BO2A, BPOFA and BPA) showed consistent effects in Puerto Calero, inside a harbour where hydrodynamics are limited and not exposed to the main current. Impacted stations in Puerto Calero were characterized by opportunistic polychaetes that dominate the macrofauna community, with a lack of amphipods (Riera et al., 2011). Consequently, these indices might be unsuitable for assessing environmental quality at this and other similar locations.

The maximum values of the BPA index (Fig. 1) always seemed higher than both of the other indices. In fact, these values corresponded to two distinct situations: (i) the absence or low abundance of amphipods and (ii) high abundance of polychaetes that were not classified among opportunistic annelids, such as on the continental shelf of Norway. For the Ekofisk site BPA values were heavily influenced by the episodic presence of the polychaete Galathowenia oculata in 2005 and 2008. This polychaete is not accounted for BO2A and BPOFA calculations. In 2008, G. oculata was by far the most abundant benthic organism in the region and showed large fluctuations in abundance between environmental surveys (Cochrane et al., 2009). In 1996, the BPOFA and BPA indices showed a peak in the impacted stations mainly due to increased abundances of the genus Spiophanes which is not accounted for BO2A. In 1997, for the Heidrun field, the BPA index showed a peak partially due to high abundances of the polychaete Euchone incolor. By 2009, the three indices showed a decrease due to decreasing abundances of the polychaete Chaetozone sp., one of the most dominant taxa in 2003 and 2006 (Mannvik et al., 2010). In 2009, however, the stations near the production facility were considered disturbed by high abundances of the bivalve Thyasira equalis, which was regarded as an indicator species when presented in large numbers (Mannvik et al., 2010). For Statfjord, BPA remained high due to the increase abundance of the polychaete Ditrupa arietina in the stations near the production facility. High abundances of this species had been previously attributed as an indicator of pollution (Vassenden et al., 2009).

In the Bay of Morlaix, the high values of BPA in the impacted RM station was related to the high abundance of some opportunistic species, such as Chaetozone gibber (Cirratulidae) or Spio decoratus and Pseudopolydora pulchra (Spionidae) (Dauvin, 2000). These two spionids, S. decoratus and $P$. pulchra, also represented a large proportion of the opportunistic polychaetes, explaining comparable trends of both BO2A and BPOFA at the control site. At the control PN site, the disappearance of the dominant amphipod Ampelisca after the Amoco Cadiz oil spill in the spring of 1978 matched for a large increase of the indices, in particular BPA. Then, there was a general trend to decreasing values in relation to the colonization of sensitive Ampelisca species, which occurred 10 years after the spill (Dauvin, 1998). The BPA index remained very high throughout the survey period in the RM impacted station due to the high densities of opportunistic polychaetes. This observation corresponded to the 'Estuarine Quality Paradox' (Dauvin, 2007; Elliott and Quintino, 2007; Dauvin and Ruellet, 2009), whereby it was difficult to detect anthropogenically induced stress including the "Amoco Cadiz" oil spill. In fact, in estuaries that were naturally organically rich, the biota was consequently similar to areas with anthropogenic eutrophication, and polychaetes proliferated naturally without supplementary organic pollution.

In the Galician Rías, differences in index values were closer than those observed in the Bay of Morlaix impacted stations where opportunistic polychaetes dominated throughout the study period. However, in this area, the abundance of opportunistic polychaetes after the "Aegean Sea" oil spill was relatively low.

On the Castellón coast, there was an increase of the abundance of polychaete families, which, despite not being considered opportunistic, exhibited typical tolerance patterns (Del-Pilar-Ruso et al., 2010). At Benicarló, there was a great difference of values between impacted and control station due to an increased abundance of the polychaete Ophryotrocha, especially in 2007 and 2008. Moreover, polychaete families not considered opportunistic for the calculation of BO2A or BPOFA indices, such as the Paraonidae, were highly abundant at the impacted sites. However, over the whole area, the polychaete assemblage was usually dominated by opportunistic species at sites closer to discharges.

In the Canarian Archipelago, at the Barranco Hondo fish cages, high BPA values were observed at the impacted stations in April 2007 due to the greater abundances of the opportunistic spionid Prionospio steeenstrupii. At the Calero site, the BPOFA and BPA peaks in June 2005 were due to the increase of the opportunistic spionid Pseudopolydora cf. paucibranchiata. BO2A showed minimum values in 2004 mainly due to the increase of amphipods, e.g. Pariambus typicus and Megamphopus cornutus. In contrast, maximum values were reported in June 2005, when amphipods showed their minimum abundances, associated with the presence of the opportunistic spionid Pseudopolydora cf. paucibranchiata.

The three indices can deserve to assess the EcoQS of the impact stations since there is a notable increase of worse status between impact and control stations in the different studied sites, i.e. the three indices showed that in general, control stations had higher ecological quality status compared with impacted stations. (Fig. 3). Among them, BPA gives a more severe classification than the two other indices. In fact, this index showed low agreement with the others while BO2A and BPOFA assigned similar EcoQS in most of the areas. However, this apparent stricter classification of BPA could be an underestimation of EcoQS, since both control and impact stations were ranked in lower categories in some areas. The use of BPA would be determined by the lack of sensitive species among polychaetes that inhabit the studied area. In general, there are two main sources of stress in coastal and marine environments: natural physical-chemical stress (e.g. estuarine areas, strong hydrodynamics on mobile sediments preventing species recruitment, acidification, sea warming, hipoxia...) and human pressures (e.g. dredging and sediment deposition, organic matter accumulation...). High values of the polychaete/amphipod ratio could occur in the absence of amphipods due to a natural disturbance. Without amphipods, or an explanation for their absence, (e.g. very high organic matter contents, anoxic crisis, recent oil spill...), it is difficult to accurately assess the quality status of a site and infer on probable causes producing the high ratio values.

Since the proposed use of the polychaetes/amphipods ratio (Gomez-Gesteira and Dauvin, 2000), its revised version with the creation of BOPA (Dauvin and Ruellet, 2007), and its transformation into BO2A (Dauvin and Ruellet, 2009), these indices had been effectively applied in many locations under various environmental conditions and with anthropogenic perturbations of different intensities. 
The polychaetes/amphipods ratio has proven successful at several geographic locations in detecting the effect of different anthropogenic pressures on benthic macrofauna. This ratio has proven especially effective to detect benthic disturbances in response to human pressures resulting from oil spills or offshore oil and gas production (e.g. Gomez and Dauvin, 2000; Nikitik and Robinson, 2003; Dauvin and Ruellet, 2007; Andrade and Renaud, 2011; Joydas et al., 2011, 2012; Sukumaran et al., 2013; Seo et al., 2014; Spagnolo et al., 2014), organic enrichment in sediments due to sewage discharge (de-la-Ossa-Carretero et al., 2009, 2012b; Vazirizadeh and Arebi, 2011; Subida et al., 2012; Pinedo et al., 2012; Serrano et al., 2014), fish farms (Keeley et al., 2012; Jahani et al., 2012; Karakassis et al., 2013; Zhang et al., 2013; Riera and de-laOssa-Carretero, 2013; Aguado-Giménez et al., 2015), organic and heavy metal contamination and diverse human activities (Dauvin et al., 2007, 2009, 2012; Munari and Mistri, 2007; Pranovi et al., 2007; Blanchet et al., 2008; Bakalem et al., 2009; Dauvin and Ruellet, 2009; Grimes et al., 2010; Pelin, 2011; Wetzel et al., 2012; Caglar and Albayrak, 2012; Saddik and Zourarah, 2013; Taupp and Wetzel, 2013), mosaic of habitats (Bouchet and Sauriau, 2008; Munari and Mistri, 2008; Lavesque et al., 2009; Do et al., 2011, 2012; Culhane, 2012), eutrophication (Afli et al., 2008; Zhang et al., 2012, 2013; Nebra et al., 2014) or in areas affected by harbour construction (Ingole et al., 2009; Riera and de-la-Ossa-Carretero, 2013), but was not efficient to detect natural long-term changes of benthic communities after a severe winter (Kröncke and Reiss, 2010). BOPA/BO2A was among the five most used indices in a review of 35 benthic quality assessment indices employed in different countries to assess the impact of 15 different human pressures (Borja et al., 2015). Moreover, in most of these studies, BOPA and BO2A were compared with other indices, mainly BENTIX, AMBI and M-AMBI (see also Boon et al., 2011; Culhane, 2012; Nebra et al., 2014; Reizopoulou et al., 2014). It appeared that, in most cases, the BOPA and $\mathrm{BO} 2 \mathrm{~A}$ indices tended to overestimate the Ecological Status of the stations (e.g. Caglar and Albayrak, 2012; Reizopoulou et al., 2014; Aguado-Giménez et al., 2015), but the comparisons showed in most of the cited studies did not take into account the revised thresholds proposed by de-la-Ossa-Carretero and Dauvin (2010), including recent publications (Nebra et al., 2014; Aguado-Giménez et al., 2015). In addition, Keeley et al. (2012) pointed out that the Ecological Status classification was underestimated by BOPA when the species richness and abundances of macro-invertebrates were very low, though the use of BOPA was not recommended for abundance $<20$ ind. However, many users of BOPA/BO2A did not apply this threshold. Others like Nebra et al. (2014) continued to use BOPA in the upper part of the transition estuarine system, while the $\mathrm{BO} 2 \mathrm{~A}$, which included the oligochaeta, was recommended in such low salinity zone of estuaries. Nevertheless, in some cases, such as the offshore platforms in the Adriatic Sea, the BOPA index seemed to yield a better assessment of stressed situations than AMBI or M-AMBI (Spagnolo et al., 2014). In the same way, as regards the dumping of dredged material in the Elbe Estuary, the BO2A index showed a better ecological status than the other indices such as AMBI and M-AMBI (Taupp and Wetzel, 2013). It had been extensively noted that BOPA (and $\mathrm{BO} 2 \mathrm{~A}$ ) indices were easier to apply than other indices because the required level of taxonomic knowledge was reduced; it was only necessary to identify amphipods, along with a reduced list of opportunistic polychaetes, and distinguished the genus Jassa from the other amphipods (Jahani et al., 2012).

The Taxonomic Sufficiency principle has often been presented as a relatively simple, useful and potentially cost-effective complement to other more demanding assessment techniques (Włodarska-Kowalczuk and Kędra, 2007; Andrade and Renaud, 2011). For the Adriatic Coastal Transitional Ecosystems (CTEs), Munari and Mistri (2010) pointed out that, in spite of an AMBI check-list containing the benthic taxa at the species level, the TS principle was already included in the AZTI list. Moreover, Munari and Mistri (2010) indicated that a genus or family level of identification for the benthic compartment of Italian CTEs might be sufficient for assessing the status of water masses.

Mistri and Munari (2008) proposed a Benthic Index based on Taxonomic Sufficiency (BITS), specifically for coastal lagoons in the Mediterranean Sea, which considered three family categories: 1) sensitive families; 2) tolerant families, and 3) opportunistic families. In their appendix, they proposed assigning ecological groups for BITS compared with BENTIX and AMBI referring to the same genus.

Apart from considering the unique response of a family to stress, in compliance with the TS concept, two other problems were raised by the faunal list drawn up by Mistri and Munari (2008): i) not all invertebrate families found in European coastal and transitional water bodies were included, and ii) it was linked to the AZTI list, which showed major temporal modifications over time (http:// ambi.azti.es/). For example, when the list was revised in July 2006, the new list included significant modifications, which resulted in moving Lagis koreni from groups 1 to 4 . Nevertheless, Lagis koreni, like Pectinariidae, remained classified as a sensitive species in the 2008 BITS list of Mistri and Munari (2008). Therefore, the 2008 BITS list should be updated before using BITS and extending its application to other water bodies.

Andrade and Renaud (2011) suggested using a simple ratio between polychaetes and amphipods as a potentially cost-effective complement to other more demanding technique for assessing soft-bottom communities. This approach reinforced the idea of making a contradistinction between all polychaetes as tolerant or opportunistic species and all amphipods as sensitive species.

Recently, Aguado-Giménez et al. (2015) proposed a BOPA-FF including the opportunistic polychaete families considered in the BOPA/BO2A indices, i.e. Capitellidae, Cirratulidae; Dorvilleidae, Pectinariidae, and Spionidae, plus also other tolerant polychaete families to the fish farming influence, i.e. Glyceridae, Nereididae, and Oweniidae, but excluding Cirratulidae, which were mostly classified as opportunistic polychaete family.

However, a further question arose: what was the limit of acceptable TS allowing an accurate assessment of the quality of the benthic environment based on macroinfauna?

First of all, there was a contrast between Andrade and Renaud's proposition (2011) assuming a unique response of amphipods to pollution and the evidence for a gradient in their sensitivity to pollution (de-la-Ossa-Carretero et al., 2012a). In fact, the presence of amphipods that were considered as stress-tolerant organisms could produce discrepancies between the calculated indices and other biotic indicators that take into account the differences in tolerance level among amphipod species (Pinedo et al., 2012, 2014). There was also a debate among benthic community experts. Some authors considered that there was a unique and homogeneous geographical response of macrobenthic species to increased organic matter, and a general effect of stress and pollution on the biogeographical distribution of a species (i.e. a given species was included in a single ecological group) (Borja et al., 2000, 2011). Others suggested that it is possible to observe different responses of species to organic matter, stress and pollution according to local and regional particularities (Grémare et al., 2009; Zettler et al., 2013). This could correspond to the existence of distinct adapted populations that can respond differently to pollution and, therefore, and be classified in several ecological groups in function to their sensitivity (Grémare et al., 2009; Zettler et al., 2013). Species sensitivities, tolerances and preferences could change along environmental gradients and between different biogeographic zones (Leonardsson et al., 2015). Hence, there was a need to adjust indicator species lists as a function of areas showing marked environmental gradients (Zettler et al., 2013; Leonardsson et al., 2015). In addition, there was a degree 
of subjectivity in all species classifications (Dauvin et al., 2010). Furthermore, the simplification of the taxonomy prior to index calculation as proposed in this present study reduced the risk of attributing a wrong Ecological Quality Status due to the difficulties of identifying certain polychaete genera and families (Dauvin, 2005). Moreover, Spilmont (2013) underlined that current benthic indicators based on species composition suffered from severe drawbacks and their practicality might have reached a dead end. He suggested developing functional indicators, which could be more relevant to detect perturbations of benthic communities.

Finally, as a major result of this study, the very strong correlation between $\mathrm{BO} 2 \mathrm{~A}$ and BPOFA indicated that the loss of information was very low when polychaetes were identified only at family level and all amphipods were considered as a single sensitive group. A criticism of indices that employ taxonomic sufficiency is that grouping of organisms in taxa belonging to a single higher taxonomic level occurs irrespective of their ecological relevance and may therefore lead to unnecessary loss of taxonomic details and reduce the ability to infer about ecological processes underlying the observed patterns (Bevilacqua et al., 2015). It has been suggested that effective ecological quality indicators need to show good discriminatory power across a full spectrum of, e.g. benthic enrichment conditions, and under a range of regional environmental conditions but these requirements are not always met even by more developed indices (Keeley et al., 2012). A solution might be to develop biotic indices calibrated for particular geographical areas combined with multivariate statistics (Aguado-Giménez et al., 2015) which may increase monitoring program costs.

In this paper, it has been shown that the simple indices evaluated can effectively identify the effects of diverse anthropogenic impacts across a large geographical scale by comparing impacted versus control areas at each site. The costs of identification, knowledge status and available expertise should be evaluated when choosing an index. Therefore, to assess anthropogenic impacts in benthic communities in areas with weak available level of knowledge, it might be suitable to use in a first step a low degree of taxonomic expertise with limited funding involving a step-wise bottom-up approach. In this way, lower degrees of TS (BPA index) could provide a general idea of the benthic community assemblages under the condition that comparisons could be made with reference stations. However, the Benthic Polychaete Opportunistic Families Amphipods (BPOFA) index could be accepted as a surrogate of the $\mathrm{BO} 2 \mathrm{~A}$ index representing a simple effective benthic indicator for assessing the ecological status of coastal water masses.

\section{Acknowledgements}

The authors thank José Luis Gomez-Gesteira from the Centro Tecnológico del Mar-Fundación CETMAR, Eduardo Cabello, s/n, 36208 Vigo, Spain-for the Galicia samples and M.S.N. Carpenter for correcting the English grammar, syntax and style. H. Andrade received financial support from the Norwegian Research Council; through the ECOBAR project (Benthic Indicators for Monitoring the Ecosystem of the Barents Sea, \#190247/S40 to P. Renaud) and Eni Norge, within the Arctic Seas Biodiversity (ASBD) project; WP4.5 Analyses of offshore benthic biodiversity. Y. Del-Pilar-Ruso and J.A. de-la-Ossa-Carretero gratefully acknowledge the staff of the Department of Marine Sciences and Applied Biology of University of Alicante for their help and CONSOMAR S.A and Entitat de Sanejament d'Aigües for the financial contribution. Rodrigo Riera is grateful to the remaining staff of CIMA SL for invaluable help during field surveys and taxonomic identification of macrofauna samples. Thanks also to Dr. Angel Borja (AZTI Tecnalia) for providing access to the Excel software sheet used to compute the Kappa analysis results

\section{References}

Afli, A., Ayari, A., Zaabi, S., 2008. Ecological quality of some Tunisian coast and lagoon locations, by using benthic community parameters and biotic indices. Estuar. Coast. Shelf Sci. 80, 269-280.

Aguado-Giménez, F., Gairin, J.I., Martinez-Garcia, E., Fernandez-Gonzalez, V., Ballester Molto, M., Cerezo-Valverde, J., Sanchez-Jerez, P., 2015. Application of taxocene surrogation and taxonomic sufficiency concepts to fish farming environmental monitoring. Comparison of BOPA index versus polychaete assemblage structure. Mar. Environ. Res. 103, 27-35.

Andrade, H., Renaud, P.E., 2011. Polychaete/amphipod ratio as an indicator of environmental impact related to offshore oil and gas production along the Norwegian continental shelf. Mar. Pollut. Bull. 62, 2836-2844.

Bakalem, A., Ruellet, T., Dauvin, J.C., 2009. Benthic indices and ecological quality of shallow Algeria fine sand community. Ecol. Indic. 9, 395-408.

Bellan-Santini, D., 1980. Relationship between populations of amphipods and pollution. Mar. Pollut. Bull. 11, 224-227.

Bevilacqua, S., Fraschetti, S., Musco, L., Terlizzi, A., 2009. Taxonomic sufficiency in the detection of natural and human-induced changes in marine assemblages: a comparison of habitats and taxonomic groups. Mar. Pollut. Bull. 58, 1850-1859.

Bevilacqua, S., Terlizzi, A., Mistri, M., Munari, C., 2015. New frameworks for species surrogacy in monitoring highly variable coastal ecosystems: applying the BestAgg approach to Mediterranean coastal lagoons. Ecol. Indic. 52, 207-218.

Blanchet, H., Lavesque, N., Ruellet, T., Dauvin, J.C., Sauriau, P.G., Desroy, N., Desclaux, C., Leconte, M., Bachelet, G., Janson, A.L., Bessineton, C., Duhamel, S., Jourde, J., Mayot, S., Simon, S., de Montaudouin, X., 2008. Use of Biotic Indices in semienclosed coastal ecosystems and transitional waters habitats - implications for the implementation of the European Water Framework Directive. Ecol. Indic. 8, 360-372.

Boon, A.R., Gittenberger, A., van Loon, W.M.G.M., 2011. Review of Marine Benthic Indicators and Metrics for the WFD and design of an optimized BEQI. Deltares report, Netherlands, pp. 59 pp.

Borja, A., Franco, J., Perez, V., 2000. A marine biotic index to the establish ecological quality of soft-bottom benthos within European estuarine and coastal environments. Mar. Pollut. Bull. 40, 1100-1114.

Borja, A., Miles, A., Occhipinti-Ambrogi, A., Berg, T., 2009. Current status of macroinvertebrate methods used for assessing the quality of European marine waters: implementing the Water Framework Directive. Hydrobiologia 633, 181-196.

Borja, A., Barbone, E., Basset, A., Borgersen, G., Brkljacic, M., Elliott, M., Garmedia, J.M. Marques, J.C., Mazik, K., Muxika, I., Neto, J.M., Norling, K., Rodriguez, J.G., Rosati, I., Rygg, B., Teixeira, H., Trayanova, A., 2011. Response of single benthic metrics and multi-metric methods to anthropogenic pressure gradients, in five distinct European coastal and transitional ecosystems. Mar. Pollut. Bull. 62, 499-513.

Borja, A., Josefson, A.B., Miles, A., Muxika, I., Olsgard, F., Phillips, G., Rodríguez, J.G., Rygg, B., 2007. An approach to the intercalibration of benthic ecological status assessment in the North Atlantic ecoregion according to the European Water Framework Directive. Mar. Pollut. Bull. 55, 42-52.

Borja, A., Marin, S.L., Muxika, I., Pino, L., Rodriguez, J.G., 2015. Is there a possibility of ranking benthic quality assessment indices to select the most responsive to different human pressures? Mar. Pollut. Bull. 97, 85-94, http://dx.doi.org/ 10.1016/j.marpolbul.2015.06.030.

Bouchet, V.M.P., Sauriau, P.G., 2008. Influence of oyster culture practices and environmental conditions on the ecological status of intertidal mudflats in the Pertuis Charentais (SW France): a multi-index approach. Mar. Pollut. Bull. 56, 1898-1912.

Caglar, S., Albayrak, S., 2012. Assessment of ecological quality status of Küçükçekmece Bay (Marmara Sea) by applying BENTIX, AMBI, BOPA and BO2A biotic indexes. Medit. Mar. Sci. 13, 198-207.

Cochrane, S., Palerud, R., Wasbotten, I. H., Mannvik, H. P., 2009. Offshore sediment survey of Region I 2008. Akvaplan-niva report no. 4315-02, Akvaplanniva, Tromsø, Norway. Available at http://www.sft.no/publikasjoner/offshore/I/ 2008Ie.pdf.

Cohen, J., 1960. A coefficient of agreement for nominal scales. Educ. Psychol. Meas. $20,37-46$

Culhane, F.E., 2012. The Use of Benthic Communities in Environmental Health Assessment. PhD thesis. Edinburgh Napier University, Edinburgh, UK, pp. 349 pp.

Dauvin, J.C., 1998. The fine sand Abra alba Community of the Bay of Morlaix twenty years after the Amoco Cadiz Oil Spill. Mar. Pollut. Bull. 36, 669-676.

Dauvin, J.C., 2000. The muddy fine sand Abra alba-Melinna palmata community of the Bay of Morlaix twenty years after the Amoco Cadiz oil spill. Mar. Pollut. Bull. $40,528-536$.

Dauvin, J.C., 2005. Expertise in coastal zone environmental impact assessments. Mar. Pollut. Bull. 50, 107-110.

Dauvin, J.C., 2007. Paradox of estuarine quality: benthic indicators and indices, consensus or debate for the future. Mar. Pollut. Bull. 55, 271-281.

Dauvin, J.C., Alizier, S., Rolet, C., Bakalem, A., Bellan, G., Gomez-Gesteira, J.L., Grimes, S., de-La-Ossa-Carretero, J.A., Del-Pilar-Ruso, Y., 2012. Response of different indices to diverse human pressures. Ecol. Indic. 12, 143-153.

Dauvin, J.C., Bachelet, G., Barillé, A.L., Blanchet, H., De Montaudouin, X., Lavesque, N., Ruellet, T., 2009. Benthic indicators and index approaches in the three main estuaries along the French Atlantic coast (Seine, Loire and Gironde). Mar. Ecol. 30, 228-240.

Dauvin, J.C., Bellan, G., Bellan-Santini, D., 2010. Benthic indicators: from subjectivity to objectivity-Where is the line? Mar. Pollut. Bull. 60, 947-953. 
Dauvin, J.C., Gomez-Gesteira, J.L., Salvande Fraga, M., 2003. Taxonomic sufficiency: an overview of its use in the monitoring of sublittoral benthic communities after oil spills. Mar. Pollut. Bull. 46, 552-555.

Dauvin, J.C., Ruellet, T., 2007. Polychaete/amphipod ratio revisited. Mar. Pollut. Bull. $55,215-224$

Dauvin, J.C., Ruellet, T., 2009. The estuarine quality paradox: Is it possible to define an ecological quality status for specific modified and naturally stressed estuarine ecosystems? Mar. Pollut. Bull. 59, 38-47.

Dauvin, J.C., Ruellet, T., Desroy, N., Janson, A.L., 2007. The ecology quality status of the Bay of Seine and the Seine estuary: Use of biotic indices. Mar. Pollut. Bull. $55,241-257$

de-la-Ossa-Carretero, J.A., Dauvin, J.C., 2010. A comparison of two biotic indices, AMBI and BOPA/BO2A, for assessing the Ecological Quality Status (EcoQS) of benthic macro-invertebrates. Transit. Waters Bull. 4, 12-24.

de la Ossa Carretero, J.A., Del Pilar Ruso, Y., Giménez-Casalduero, F., Sánchez Lizaso, J.L., 2008. Effect of sewage discharge in Spisula subtruncata (da Costa 1778) populations. Arch. Environ. Con. Toxicol. 54, 226-235.

de-la-Ossa-Carretero, J.A., Del-Pilar-Ruso, Y., Giménez-Casalduero, F., SánchezLizaso, J.L., 2009. Testing BOPA index in sewage affected soft-bottom communities in the north-western Mediterranean. Mar. Pollut. Bull. 58, 332-340.

de-la-Ossa-Carretero, J.A., Del-Pilar-Ruso, Y., Giménez-Casalduero, F., SánchezLizaso, J.L., 2010. Sensitivity of tanaid Apseudes latreillei (Milne-Edwards) populations to sewage pollution. Mar. Environ. Res. 69, 309-317.

de-la-Ossa-Carretero, J.A., Del-Pilar-Ruso, Y., Giménez-Casalduero, F., SánchezLizaso, J.L., Dauvin, J.C., 2012a. Sensitivity of amphipods to sewage pollution. Estuar. Coast. Shelf Sci. 96, 129-138.

de-la-Ossa-Carretero, J.A., Simboura, N., Del-Pilar-Ruso, Y., Pancucci-Papadopoulou, M.A., Giménez-Casalduero, F., Sánchez-Lizaso, J.L., 2012b. A methodology for applying Taxonomic Sufficiency and benthic biotic indices in two Mediterranean areas. Ecol. Indic. 23, 232-241.

Del-Pilar-Ruso, Y., de-la-Ossa-Carretero, J.A., Loya-Fernández, A., Ferrero-Vicente, L.M., Giménez-Casalduero, F., Sánchez-Lizaso, J.L., 2009. Assessment of soft bottom Polychaeta assemblage affected by a spatial confluence of impacts: sewage and brine discharges. Mar. Pollut. Bull. 58, 776-782.

Del-Pilar-Ruso, Y., de-la-Ossa-Carretero, J.A., Giménez-Casalduero, F., SánchezLizaso, J.L., 2010. Sewage treatment level and flow rates affect polychaete assemblages. Mar. Pollut. Bull. 60, 1930-1938.

Devlin, M., Best, M., Haynes, D., 2007. Implementation of the water framework directive in European marine waters. Mar. Pollut. Bull. 55, 1-297.

Diaz, R.J., Solan, M., Valente, R.M., 2004. A review of approaches for classifying benthic habitats and evaluating habitat quality. J. Environ. Manag. 73, 165-181.

Dimitriou, P.D., Apostolaki, E.T., Papageorgiou, N., Reizoploulou, S., Simboura, N., Arvanditis, C., Karakassis, I., 2012. Meta-analysis of a large data set with Water Framework Directive indicators and calibration of Benthic Quality Index at the family level. Ecol. Indic. 20, 101-107.

Do, V.T., de Montaudouin, X., Lavesque, N., Blanchet, H., Guyard, H., 2011. Seagrass colonization: knock-on effects on zoobenthic community, populations and individual health. Estuar. Coast. Shelf Sci. 95, 458-469.

Do, V.T., de Montaudouin, X., Blanchet, H., Lavesque, N., 2012. Seagrass burial by dredged sediments: benthic community alteration, secondary production loss, biotic index reaction and recovery possibility. Mar. Pollut. Bull. 64, 2340-2350.

Ellis, D., 1985. Taxonomic sufficiency in pollution assessment. Mar. Pollut. Bull. 16, 459

Elliott, M., Quintino, V.M., 2007. The estuarine quality paradox, environmental homeostasis and the difficulty of detecting anthropogenic stress in naturally stressed areas. Mar. Pollut. Bull. 54, 640-645.

Fleiss, J.L., Cohen, J., 1973. The equivalence of weighted Kappa and the intraclass correlation coefficient as measures of reliability. Educ. Psychol. Meas. 33. 613-619.

Glémarec, M., Hily, C., 1981. Perturbations apportées à la macrofaune benthique de la baie de Concarneau par les effluents urbains et portuaires. Acta Oecol. Acta Appl. 2, 139-150.

Gomez-Gesteira, J.L., Dauvin, J.C., 2000. Amphipods are good bioindicators of the impact of oil spills on soft-bottom macrobenthic communities. Mar. Pollut. Bull. 40, 1017-1572.

Gomez-Gesteira, J.L., Dauvin, J.C., 2005. Impact of the Aegean Sea oil spill on the subtidal fine sand macrobenthic community of the Ares-Betanzos Ría (Northwest Spain). Mar. Environ. Res. 60, 289-316.

Gomez-Gesteira, J.L., Dauvin, J.C., Salvande Fraga, M., 2003. Taxonomic levels for assessing oil spill effects on soft-bottom sublittoral benthic communities. Mar. Pollut. Bull. 46, 562-572

Grall, J., Glémarec, M., 1997. Using biotic indices to estimate macrobenthic community perturbations in the Bay of Brest. Estuar. Coast. Shelf Sci. 44, 43-53.

Grémare, A., Labrune, C., Vanden Berghe, E., Amouroux, J.M., Bachelet, G., Zettle, M.L., Vanaverbek, J., Fleische, D., Bigo, L., Maire, O., Deflandre, B., Craeymeersch, J., Degraer, S., Dounas, C., Duineveld, G., Heip, C., Herrmann, M., Hummel, H., Karakassis, I., Kedra, M., Kendall, M., Kingston, P., Laudien, J., Occhipinti-Ambrogi, A., Rachor, E., Sardá, R., Speybroeck, J., Van Hoey, G., Vincx, M., Whomersley, P., Willems, W., Wlodarska-Kowalczuk, M., Zenetos, A., 2009. Comparison of the performances of two biotic indices based on the MacroBen database. Mar. Ecol. Progr. Ser. 382, 297-311

Grimes, S., Ruellet, T., Dauvin, J.-C., Boutiba, Z., 2010. Ecological quality status of the soft-bottom communities on the algerian coast: general patterns and diagnosis. Mar. Pollut. Bull. 60, 1969-1977.
Ingole, B., Sivadas, S., Nanajkar, M., Sautya, S., Nag, A., 2009. A. comparative study of macrobenthic community from harbours along the central west coast of India. Environ. Monit. Assess. 54, 135-146.

Jahani, N., Nabavi, S.N.B., Dehghan Madiseh, S., Mortezaie, S.R.S., Fazeli, N., 2012. The effect of marine fish cage culture on benthic communities using BOPA index in Ghazale Creek (Persian Gulf). Iran J. Fish. Sci. 11, 78-88.

Joydas, T.V., Krishnakumar, P.K., Qurban, M.A., Ali, S.M., Al-Suwailem, A., AlAbdulkader, K., 2011. Status of macrobenthic community of Manifa-Tanajib Bay System of Saudi Arabia based on a once-off sampling event. Mar. Pollut. Bull. 62 1249-1260.

Joydas, T.V., Qurban, M.A., Al-Suwailem, A., Krishnakumar, P.K., Nazeer, Z., Cali, N.A., 2012. Macrobenthic community structure in the northern Saudi waters of the gulf, 14 years after the 1991 oil spill. Mar. Pollut. Bull. 64, 325-335.

Karakassis, I., Dimitriou, P.D., Papageorgiou, N., Apostolaki, E.T., Lampadariou, N., Black, K.D., 2013. Methodological considerations on the coastal and transitional benthic indicators proposed for the Water Framework Directive. Ecol. Indic. 29 26-33.

Keeley, N.B., Forrest, B.M., Crawford, C., Macleod, C.M., 2012. Exploiting salmon farm benthic enrichment gradients to evaluate the regional performance of biotic indices and environmental indicators. Ecol. Indic. 23, 453-466.

Kröncke, I., Reiss, H., 2010. Influence of macrofauna long-term natural variability on benthic indices used in ecological quality assessment. Mar. Pollut. Bull. 60, 58-68.

Lavesque, N., Blanchet, H., de Montaudouin, X., 2009. Development of a multimetric approach to assess perturbation of benthic macrofauna in Zostera noltii beds. J. Exp. Mar. Biol. Ecol. 368, 101-112.

Landis, J.R., Kosch, G.G., 1977. The measurement of observer agreement for categorical data. Biometrics 33, 159-174.

Leonardsson, K., Blomqvist, M., Magnusson, M., Wikström, A., Rosenberg, R., 2015 Calculation of species sensitivity values and their precision in marine benthic faunal quality indices. Mar. Poll. Bull. 93, 94-102.

Mannvik, H.P., Wasbotten, I.H., Holm, M.H., Cochrane, S., 2010. Miljøundersøkelse i Region VI, 2009. Akvaplan-niva report no 4664-01, Akvaplan-niva, Tromsø Norway. http://www.sft.no/publikasjoner/offshore/VI/2009VI.pdf.

Martinez-Haro, M., Beiras, R., Bellas, J., Capela, R., Coelho, J.P., Lopes, I., MoreiraSantos, M., Reis-Henriques, A.M., Ribeiro, R., Santos, M.M., Marques, J.C., 2015. A review on the ecological quality status assessment in aquatic systems using community based indicators and ecotoxicological tools: what might be the added value of their combination? Ecol. Indic. 48, 8-16.

Mistri, M., Munari, C., 2008. BITS: a SMART indicator for soft-bottom, non-tida lagoons. Mar. Pollut. Bull. 56, 587-599.

Monserud, R., Leemans, R., 1992. Comparing global vegetation maps with the Kappa statistic. Ecol. Model. 62, 275-293.

Munari, C., Mistri, M., 2007. Evaluation of the applicability of a fuzzy index of ecosystem integrity (FINE) to characterize the status of Tyrrhenian lagoons. Mar Environ. Res. 64, 629-638.

Munari, C., Mistri, M., 2008. The performance of benthic indicators of ecological change in Adriatic coastal lagoons: throwing the baby with the water? Mar. Pollut. Bull. 56, 95-105

Munari, C., Mistri, M., 2010. Towards the application of the Water Framework Directive in Italy: assessing the potential of benthic tools in Adriatic coasta transitional ecosystems. Mar. Pollut. Bull. 60, 1040-1050.

Musco, L., Terlizzi, A., Licciano, M., Giangrande, A., 2009. Taxonomic structure and the effectiveness of surrogates in environmental monitoring: a lesson from polychaetes. Mar. Ecol. Progr. Ser. 383, 199-210.

Musco, L., Mikac, B., Tataranni, M., Giangrande, A., Terlizzi, A., 2011. The use of coarser taxonomy in the detection of long-term changes in polychaete assemblages. Mar. Environ. Res. 71, 131-138.

Nebra, A., Caïola, N., Muñoz-Camarillo Rodriguez-Climent, S., 2014. Towards a suitable ecological status assessment of highly stratified Mediterranean estuaries: a comparison of benthic invertebrate fauna indices. Ecol. Indic. 46 177-187.

Nikitik, C.C.S., Robinson, A.W., 2003. Patterns in benthic populations in the Milford Haven waterway following the 'Sea Empress' oil spill with special reference to amphipods. Mar. Pollut. Bull. 46, 1125-1141.

Pearson, T.H., Rosenberg, R., 1978. Macrobenthic succession in relation to organic enrichment and pollution of the marine environment. Oceanogr. Mar. Biol. Ann. Rev. 16, 229-311.

Pelin, V., 2011. Selection of evaluating bioindicators on ecosystem health in Yundang lagoon, Xiamen. Report in the International Summer Water Resources Research School VVR05, 14 pp.

Pinedo, S., Jordana, E., Salas, F., Subida, M.D., Garcia Adiego, E., Torres, J., 2012. Testing MEDOCC and BOPA indices in shallow soft-bottom communities in the Spanish Mediterranean coastal waters. Ecol. Indic. 19, 98-105.

Pinedo, S., Jordana, E., Ballesteros, E., 2014. A Critical analysis on the response of macroinvertebrate communities along disturbance gradients: description of MEDOCC (MEDiterranean OCCidental) index. Mar. Ecol. 36, 141-154, http://dx. doi.org/10.1111/maec.12126.

Pinto, R., Patricio, J., Baeta, A., Fath, B.D., Neto, J.M., Marques, J.C., 2009. Review and evaluation of estuarine biotic indices to assess benthic condition. Ecol. Indic. 9 , $1-25$.

Ponti, M., Vadrucci, M.R., Orfanidis, S., Pinna, M., 2009. Biotic indices for ecologica status of transitional water ecosystems. Transit. Waters Bull. 3, 32-90.

Pranovi, F., Da Ponte, F., Torricelli, P., 2007. Application of biotic indices and relationship with structural and functional features of macrobenthic community in 
the lagoon of Venice: an example over a long time series of data. Mar. Pollut. Bull. 54, 1607-1618.

Ré, A., Freitas, R., Sampaio, L., Rodrigues, A.M., Quintino, V., 2009. Estuarine sediment acute toxicity testing with the European amphipod Corophium multisetosum Stock, 1952. Chemosphere 76, 1323-1333.

Reish, D.J., 1959. An ecological study of pollution in Los Angeles-Long Beach Harbors, California. Allan Hancock Foundation Publications. Occasional papers, 22, 1-117.

Reizopoulou, S., Simboura, N., Sigala, K., Barbone, E., Alefli, F., Kaisakis, G., Rosati, I., Basset, A., Nicolaidou, A., 2014. Assessment of the ecological status of the Mediterranean coastal lagoons using macroinvertebrates. Comparison of the most commonly used methods. Medit. Mar. Sci. 15, 602-612.

Riera, R., de-la-Ossa-Carretero, J.A., 2013. Response of benthic opportunistic polychaetes and amphipods index to different perturbations in coastal oligotrophic areas (Canary archipelago, North East Atlantic Ocean). Mar. Ecol. 35, 354-366.

Riera, R., Monterroso, O., Rodríguez, M., Pérez, O., Ramos, E., González, M., Durán, C., 2009. The Water Framework Directive (WFD) as a tool to determine the quality of wáter masses and marine seabeds in Tenerife. I Jornadas Nacionales de Seguridad y Contaminación Marina, 25 pp.

Riera, R., Monterroso, O., Rodríguez, M., Ramos, E., 2011. Biotic indexes reveal the impact of harbour enlargement on benthic fauna. Chem. Ecol. 27, 311-326.

Riera, R., Sánchez-Jerez, P., Rodríguez, M., Monterroso, O., 2014. Artificial marine hábitats favor a single sifh species on a long-term scale: the dominance of Boops boops around off-shore fish cages. Sci. Mar. 78, 505-510.

Riera, R., Tuya, F., Ramos, E., Rodríguez, M., Monterroso, O., 2012. Variability of macrofaunal assemblages on the surroundings of a brine disposal. Desalin 291, 94-100,

Rombouts, I., Beaugrand, G., Artigas, L.F., Dauvin, J.C., Gevaert, F., Goberville, E., Kopp, D., Lefebvre, S., Luczak, C., Spilmont, N., Travers-Trolet, M., Villanueva, M.C., Kirby, R.R., 2013. Evaluating marine ecosystem health: case studies of indicators using direct observations and modelling methods. Ecol. Indic. 24, 353-363.

Saddik, M., Zourarah, B., 2013. Assessment of environmental and ecological quality status in the NE of Moroccan Mediterranean coast. Am. Int. J. Res. Form. Appl. Nat. Sci. 13-245, 93-98.

Seo, J.Y., Kim, M., Lim, H.S., Choi, J.W., 2014. The macrofaunal communities in the shallow subtidal areas for the first 3 years after the Hebei Spirit oil spill. Mar. Pollut. Bull. 82, 208-220.

Serrano, A.D., Tena, J., Torres, J., 2014. Suitability of the BOPA index for the assessment of the ecological quality status of the coastal waters off the Gulf of Valencia. Conference Paper. International Symposium of Marine Science 2014. at Las Palmas de Gran Canaria, Spain, abstract, 1 p.

Simboura, N., Zenetos, A., 2002. Benthic indicators to use in Ecological Quality classification of Mediterranean soft bottom marine ecosystems, including a new Biotic Index. Medit. Mar. Sci. 3, 77-111.

Soares-Gomes, A., Mendes, C.L.T., Tavares, M., Santi, L., 2012. Taxonomic sufficiency of polychaete taxocenes for estuary monitoring. Ecol. Indic. 15, 149-156.

Spagnolo, A., Punzo, E., Santelli, A., Scarcella, G., Strafella, P., Grati, F., Fabi, G., 2014. Offshore platforms: comparison of five benthic indicators for assessing the macrozoobenthic stress levels. Mar. Pollut. Bull. 65, 55-65.

Spilmont, N., 2013. The future of benthic indicators: moving up to the intertidal. Open J. Mar. Sci. 3, 76-86.
Subida, M.D., Drake, P., Jordana, E., Marvric, B., Pinedo, S., Simboura, N., Torres, J., Salas, F., 2012. Response of different biotic indices to gradients of organic enrichment in Mediterranean coastal waters: implications of non-monotonic responses of diversity measures. Ecol. Indic. 19, 106-117.

Sukumaran, S., Vijapure, T., Jyoti Mulik, J., Rokade, M.A., Gajbhiye, S.N., 2013. Macrobenthos in anthropogenically influenced zones of a coralline marine protected area in the Gulf of Kachchh, India. J. Sea Res. 76, 39-49.

Tataranni, M., Maltagliati, F., Floris, A., Castelli, A., Lardicci, C., 2009. Variance estimate and taxonomic resolution: an analysis of macrobenthic spatial patterns at different scales in a Western Mediterranean coastal lagoon. Mar. Environ. Res. 67, 219-229.

Tataranni, M., Lardicci, C., 2010. Performance of some biotic indices in the real variable world: a case study at different spatial scales in North-Western Mediterranean Sea. Environ. Pollut. 158, 26-34.

Taupp, T., Wetzel, M.A., 2013. Relocation of dredged material in estuaries under the aspect of the Water Framework Directive-a comparison of benthic quality indicators at dumping areas in the Elbe estuary. Ecol. Indic. 34, 323-331.

Terlizzi, A., Bevilacqua, S., Fraschetti, S., Boero, F., 2003. Taxonomic sufficiency and the increasing insufficiency of taxonomic expertise. Mar. Pollut. Bull. 46, $556-561$

Underwood, A.J., 1997. Experiments in Ecology: their Logical Design and Interpretation Using Analysis of Variance. Cambridge University Press, Cambridge, pp. 504 pp.

Van Hoey, G., Borja, A., Birchenough, S., Buhl-Mortensen, L., Degraer, S., Fleischer, D. Kerckhof, F., Magni, P., Muxika, I., Reiss, H., Schröder, A., Zettler, M.L., 2010. The use of benthic indicators in Europe: from the Water Framework Directive to the Marine Strategy Framework Directive. Mar. Pollut. Bull. 60, 2187-2196.

Vassenden, G., Heggøy, E., Johansen, P.O., Botnen, H., 2009. Miljøovervåkning av olje- og gassfelt i Region IV I 2008. Unifob, Bergen, Norway. http://www.sft.no/ publikasjoner/offshore/IV/2008IV.pdf.

Vazirizadeh, A., Arebi, I., 2011. Study of macrofaunal communities as indicators of sewage pollution in intertidal ecosystems: a case study in Bushehr (Iran). World J. Fish Mar. Sci. 3, 174-182.

Wetzel, M.A., von der Ohe, P.C., Manz, W., Koop, J.H.E., Wahrendorf, D.S., 2012. The ecological quality status of the Elbe estuary. A comparative approach on different benthic biotic indices applied to a highly modified estuary. Ecol. Indic. 19 $118-129$.

Włodarska-Kowalczuk, M., Kędra, M., 2007. Surrogacy in natural patterns of benthic distribution and diversity: selected taxa versus lower taxonomic resolution. Mar. Ecol. Progr. Ser. 351, 53-63.

Zettler, M.L., Proffitt, C.E., Darr, A., Degraer, S., Devriese, L., Greathead, C., Kotta, J., Magni, P., Martin, G., Reiss, H., Speybroeck, J., Tagliapietra, D., Van Hoey, G., Ysebaert, T., 2013. On the myths of indicator species: issues and further consideration in the use of static concepts for ecological applications. Plos One 8, 78219.

Zhang, Y., Zhenbo, L., Xu, Z.F., Chen, W., Chen, J.Q., 2012. Impacts of environmental pollution on macrobenthos diversity in Xiaoqing estuary of Shandong Province, East China. Chin. J. Ecol. 31, 381-387.

Zhang, Y., Zhenbo, L., Guan, B., Liu, Y., Li, S., Ma, Y., Yu, J., Li, Y., 2013. Status of macrobenthic community and its relationships to trace metals and natural sediment characteristics. Clean-Soil Air Water 41, 1027-1034. 